p. i 44 キネシオロジー的研究

287. 投げの研究（その3）

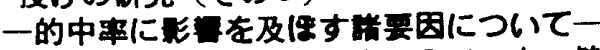

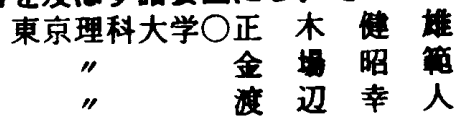

!. 前回にひきつづき，体力要素をとりのぞいて技能 要素のみをとり出し，その成立条件をさくろうという意 図で，ボールの正破投けをとりあけた。

2. 垂直標的（直佳 $20,40,60,80,100 \mathrm{~cm}$ ) K対し $5 \mathrm{~m}$ の距噰から，硬式ボールを使用して，なるべく中

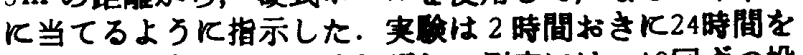
通しておこなつたが，それぞれの即定には，10回ずつ投 けさせた。被馀者は成年男子 2 名，同女子 4 名てある. またこの测定に先だつて, 同時刻に, フリッカー值, 反 态時間，記憶力の検查もおこなつた.

3. Wくつかの標的に対する的中率の日変功をみると 日変功より，学習の效果かより大きくみられる女子につ いても，それは直佳 $80,100 \mathrm{~cm}$ の標的について然宗され るのみであつた.これに対して，男子は，40 cn以上の標 的について若干の学習効果が䘽客されたが $20 \mathrm{~cm} の$ 標的に ついては，ほとんど日変䖝がみられなかつた。

またこれらの変動のあつた時点での, フリッカー值, 反応時間, 記憶力との対态は，必ずしも証められなかつ た。

4. 最も中心に近かつた值を「最大值」として，その 出現回飞おける須度をみると, 第1 回目, 第 3 回目, 第 6 回目，第iO回目に peak が認められた.

また最大值の出現間事とその類度を示したのか，第

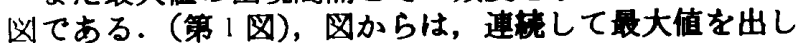
ている場合が最も多く、一つおき，二つおき，三つおき
と次第に低下していることがわかる.これは中心に対す

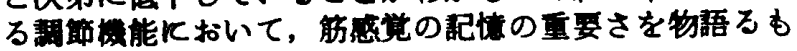
のと思われる.

地の出牫闻而と

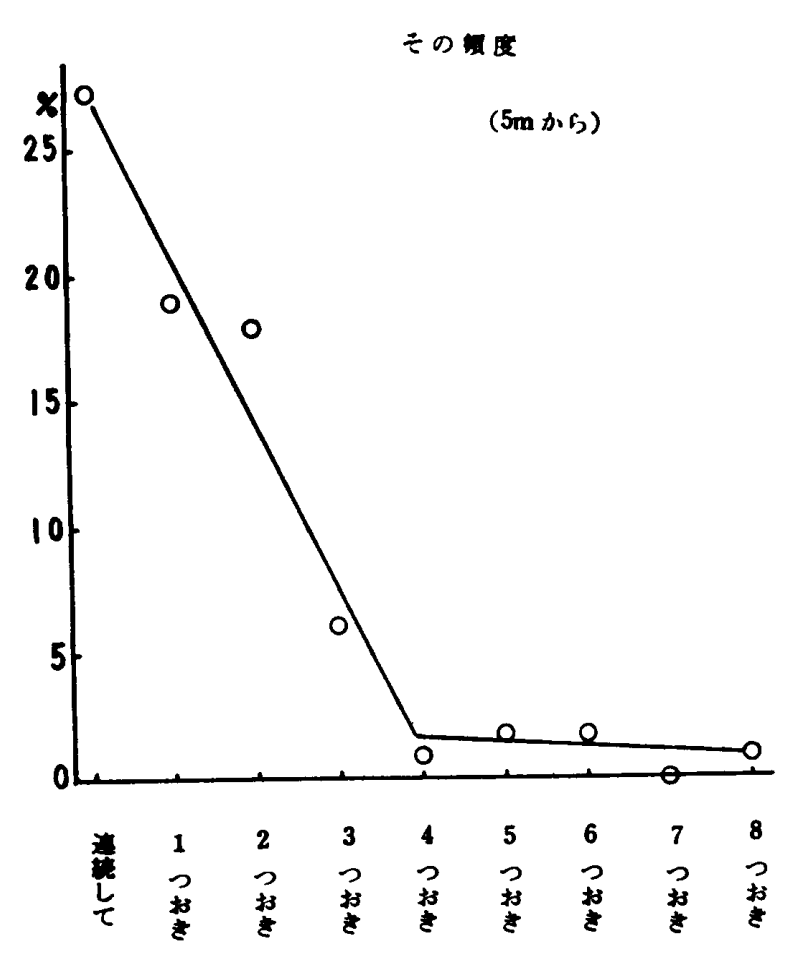

\section{8. 咕力湴としての人闪の特性の研究}

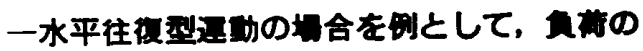
大きさおよひ内容による到について一

東京教育大学スポーツ研究所○衣 笠 篮 小佐 文 爑

いろいろなスポーツや，労倾作菜を行なつている時の

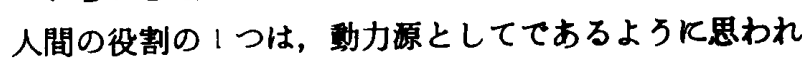
ろ.それて，このような人間の能力を研究するために従 来いろいろなェルゴィーターが用いられているよろK思 ろ.トレッドミルをはじめとして，自伝車エルゴィータ 一、腕エルゴメーター，慣性エルゴメータ一等がある. ところで，侻来のこれらのエルゴィーターて怪視されて いることの中に，まだ相当重要だと思われる事柄が牫さ れているよろに思う。

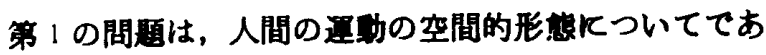
りる. 侻来のェルゴメーターにあまりみられないるのの 中で, 人間の国轩の!つの基本的形式として, 今回は上 肢（上腕）の水平往樭置扐を例にとつてみた，次に第 2 の間题点は負荷についててある，私どあは，特に負荷の
力学的内容ということと盖目した. 負荷の力学的基本要 素があると考えた．その第1は，粘性の負荷て，これ は、変位 $\mathrm{x}$ の 1 回儌分である速度に比例した抵抗力をあ つものである，第 2 は惯性の負荷であり，変位 $\mathrm{x}$ の 2 回 砤分であろ加速度に比例した抵抗力をもつものである。

第 3 は，弹性の負荷であり，x火比例した抵抗力をるつ

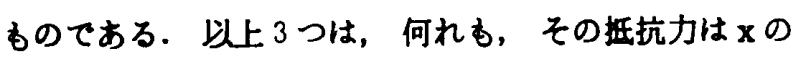
関数の形で表現できるが，第 4 番目に $\mathrm{x}$ とは全く関係な く，常に一定の 抵抗力をるつ負荷が考えられるこの 他飞あまだあるが，一応この 4 つを基本要素として，実 紫の军都の負荷は，これら4者のくみあわせとして考え た.

第 3 に問題としたことは，剆定方法についてであり，

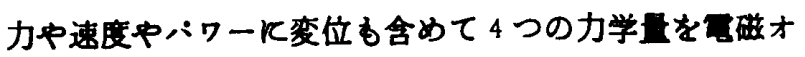
ッシ口の記䟿纸の上飞同時飞波形として記録する方法を とつた.

以上の意暴のすとに，私どすは，上肢エルゴメーター を試作した。 